\title{
ROLE OF CRITICAL SUCCESS FACTORS (CSF) IN THE IMPLEMENTATION OF SIX SIGMA IN HOSPITALS: A PRELIMINARY STUDY IN PAKISTAN
}

\author{
Muzna Abid', Osama Majeed Butt², Quratul Aan³, Bushra Rashid4', Nanthini Sri Devit
}

1. Institute of Quality \& Technology Management, University of the Punjab, Pakistan

2. Department of Electrical Engineering, University of the Punjab, Pakistan

3. Zeppelin Universitat, Friedrichshafen, Baden-Württemberg, Germany

4. Department of Maritime Science and Technology, Faculty of Science and Defence Technology, National Defence University of Malaysia, Malaysia

Correspondence: osama.ee@pu.edu.pk

\begin{abstract}
Six sigma can enable us to determine the possible solutions to most of the problems which are being faced by the healthcare system of Pakistan. Six sigma is a viable way to make healthcare rapid and proficient. It is already being successfully utilized around the globe in service as well as manufacturing sector. This research is a preliminary study; conducted, in an attempt, to highlight the issues in healthcare like scarcity of medicines, inefficiency of medical staff, insufficient beds and low doctor/patient ratio in hospitals of Pakistan. A proposal is proposed for a viable solution in the form of six-sigma. For this study, six-sigma identify the potential issue by involving all employees of the targeted sectors. Collection of primary data was done from employees at quality departments in hospitals and via survey. The importance of critical success factors in the public and private hospitals of Pakistan was determined by the aforementioned survey. Critical analysis pointed out that most of the employees were unaware of the quality initiatives and six-sigma.
\end{abstract}

\section{KEYWORDS}

critical success factor, healthcare, six-sigma, total quality management

\section{INTRODUCTION}

Human capital is determined by the health conditions in any country. [1] The health systems research has been a neglected area. More than three decades back, private health insurance was introduced in Pakistan, but no importance was given to this matter. According to WHO World Health Report Pakistan was listed as one of the 57 countries with critical workforce deficiency. [2] Three most common cited reasons of malfunctioning in healthcare sector of Pakistan are: (1) lack of availability of medicines, (2) uncooperative staff, (3) Inaccessible facilities. And the total availability of beds in these hospitals is very low. Most of the people go directly to the secondary or tertiary healthcare hospitals. Pakistan is one of those countries which under-utilizes its healthcare facilities. [3] Healthcare sector of Pakistan needs special attention. According to UNICEF, "despite significant improvements over the past two decades, Pakistan ranks towards the bottom among other countries when it comes to infant and neonatal mortality". [4] The healthcare system of Pakistan shows a high population growth rate. The indicators that show this rate are not even comparable with countries of South Asia. Over the last years, investments that have been made in health sector are low. [5] The healthcare expenditure in Pakistan is determined by its socio-economic factors. [1] In order to provide solutions to the above mentioned 
problems a perspective study has been conducted which may be helpful in implementing six sigma at hospitals in future. [6, 7] The aim of this research is to find out the service quality levels of hospitals in Pakistan. Whether they have any idea about Six Sigma or not? What quality initiatives they have taken so far? Are their employees trained for quality or not? How do they measure their service quality? The inclusive objective of the research is to enhance the understanding of quality practices of hospitals and find out about critical success factors that may be helpful in implementing this concept which may help in order to reduce waste and improve service quality. The objective of the study is to determine CSF /Critical Success Factors) which are important for the implementation of six-sigma in private and public hospitals of Pakistan.

\subsection{EVOLUTION OF SIX-SIGMA}

"Six sigma is highly disciplined approach used to reduce the process variation to such a great extent that the level of defects is drastically reduced to less than 3.4 per million processes, product or service opportunities. The approach relies heavily on statistical tools which, though known earlier, were primarily limited to use by statisticians and quality professionals" [8]. It was initially launched by Motorola in late 1980s. [9] In 1986, Bill Smith, an engineer and scientist who worked at Motorola's Communication Department, introduced the concept of Six Sigma. Bill Smith is known as "Father of Six Sigma". Six sigma roots can be traced back to tools and techniques used by quality Gurus. [8] The concept of TQM "Continuous improvement" can be achieved through 60. [10] Six sigma evolved from TQM. It is a rigorous method which involves proven quality techniques which are integrated from the work of many quality pioneers. Statisticians use the Greek letter $\sigma$, to measure variability in any process. And to measure the performance of any organization sigma level is used. [9] Six sigma uses standard quality techniques which are part of TQM. It is a management strategy actually which focuses on reducing variation and causes that was responsible of defects in first place. [10] The aim of six-sigma is to eliminate variation on the basis of customer definition of quality. [11] During the last two decades six sigma has been approached by many companies around the world. Six sigma's main objective is to remove variation in processes or products produced and to achieve quality levels of less than 3.4 defects per million opportunities (DPMO). [8, 12] Because improved process leads us to customer satisfaction, increased market share, increased yield, increased profitability. [13]

\subsection{SIX-SIGMA APPROACH TO SERVICE INDUSTRY}

Six Sigma could be very useful to find solutions of healthcare problems because it utilizes statistical tools and proper management framework to identify the root cause of the problems rather than jumping to abrupt solution. [14] The main reason to implement Six Sigma in service industry is that customers feel "process variability". It can also improve customer satisfaction and service performance. [13] In healthcare system patients are the customers. Quality is now playing major role in healthcare sector as patients are able to choose their healthcare providers based on the quality treatment they get. [15-17] At the same time it has now become a culture to ask patients perspective about service quality they receive in order to organize their staff and for the sake of continuous improvement. [18]

\subsection{SIX-SIGMA APPROACH TO HEALTH-CARE INDUSTRY}

A supreme amount of benefits can be achieved through six-sigma in healthcare sector. If six-sigma technical strategy is combined with the cultural strategy only then success can be achieved because there is lot of human elements involved in patient care as compared to machine elements. [19] In healthcare system patients are the customers. Quality is now playing major role in healthcare sector as patients are able to choose their healthcare providers based on the quality treatment they get. At the same time, it has now become a

culture to ask patients perspective about service quality they receive in order to organize their staff and for the sake of continuous improvement. There are three approaches to improve the customer (patient) satisfaction:
1. Measurement of patient's point of view.
2. Improving the outcome of patients.
3. Use of six sigma approach [20]

\section{METHODOLOGY}

In 1979 Rockart popularized the idea of Critical Success Factor. [10] These factors are necessary for the success or failure of six-sigma. In order to achieve certain level of quality management these critical success factors are important. Traditionally most studies were about Total Quality Management critical success factors. CSFs are actually those key aspects as shown in figure 1 of any organization that are critical to achieve its goals and produce satisfactory results. They are the key factors to achieve organization's vision and to attain customer 
satisfaction in order to provide quality service. According

to recent literature there is tremendous interest in

implementing six sigma in service sector. [10]

FIG. 1 CRITICAL SUCCESS FACTORS OF AN ORGANIZATION [10]

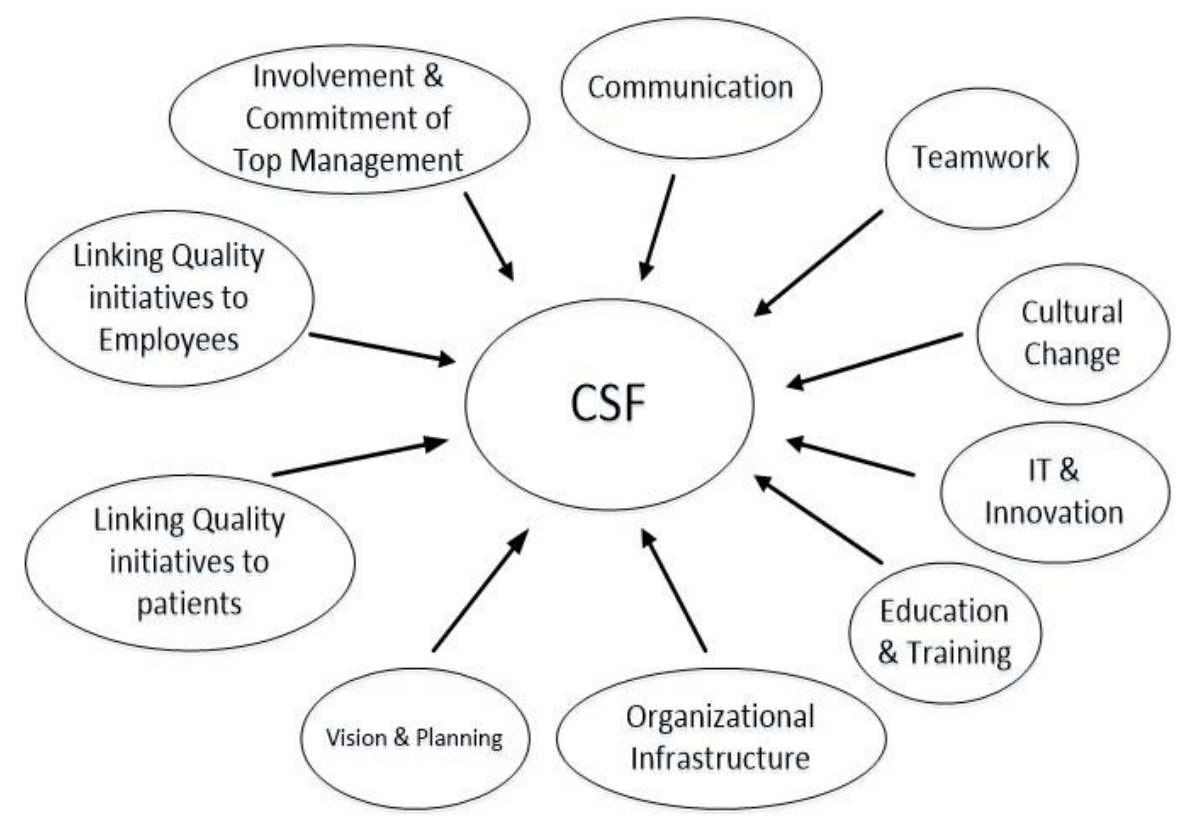

\subsection{SURVEY DESIGN}

For the research conducted, population chosen for the survey was highly educated and professionals, like people who are doctors but working in the quality departments of hospitals or at administrative departments. Data has been collected from private and public hospitals of Pakistan. The survey responses were apprehended from different cities in Pakistan including Lahore, Islamabad, Rawalpindi, Gujranwala, Peshawar, and Multan. The responses were distributed among respondents in soft as well as in hard form. Questionnaire design was targeted to know about the quality conditions in hospitals and whether they are inclined towards quality or not? Some questions were asked about quality certifications and trainings, so that an idea can be obtained about how quality driven they are. The questionnaire utilized Likert type scale, where respondents could choose from five options including Very important, important, neutral, and not so important to not important. The analysis of data was acquired through survey is based on descriptive as well as inferential analysis. T-test and Pearson correlation test were used to analyse the data of this study.

\subsection{HYPOTHESIS TESTING USING INDEPENDENT SAMPLE T-TEST}

Independent sample t-test, it exhibited statistical evidence that there is a significant difference in the means of two groups or not and to determine which group grant more significance to a factor on which hypothesis testing was performed. The CSFs are analysed by Independent sample t-test. Independent sample t-test is used to compare the means of two samples from the same population. Grouping variable in this case is sector (Public/private). Both samples are independent and cannot affect each other. The comparison is between two sets of values from one variable. Each variable has a hypothesis and on the basis of the t-test result hypothesis is rejected or accepted. Following are the hypothesis based on factors in Fig 1.

$\mathrm{H} \mathrm{l}=$ Mean scores of "involvement and commitment of top management" variable in public and private sector does not vary.

$\mathrm{H} 2$ = Mean scores of "organizational infrastructure" variable in public and private sector does not vary.

H3=Mean scores of" vision \& planning" variable in public and private sector does not vary.

$\mathrm{H} 4$ = Mean scores of "linking quality initiatives to employees" variable in public and private sector does not vary.

H5 =Mean scores of" linking quality initiatives to patients" variable in public and private sector does not vary. 
H6 =Mean scores of" project management skills" variable in public and private sector does not vary.

H7 =Mean scores of" information technology and innovation" variable in public and private sector does not vary.

$\mathrm{H} 8=$ Mean scores of "communication" variable in public and private sector does not vary.

H9 = Mean scores of "Team work" variable in public and private sector does not vary.

$\mathrm{H} 10$ = Mean scores of "cultural change" variable in public and private sector does not vary.
$\mathrm{H} 1 \mathrm{l}=$ Mean scores of "education \& training" variable in public and private sector does not vary.

\subsection{PEARSON CORRELATION TEST}

Pearson Correlation test was performed to show which factors were more connected. A correlation coefficient represented the strength and direction among all CSFs. If correlation coefficient is greater than 0.5 , the relationship is considered strong and greater than 0.8 is considered very strong. The table 1.3 shows the correlations among CSF of six-sigma. All the descriptive analysis of introductory questions in the survey are shown in table 1.

\section{TABLE 1 DESCRIPTIVE ANALYSIS}

\section{DESCRIPTIVE ANALYSIS OF RESPONSES}

Percentage of responses collected:

Doctor/Patient ratio:

Ratio $1 / 10$

Ratiol/15

Ratio $1 / 20$

Ratio $1 / 25$

Other

Measure, check and control the variations \& failures in following concepts:

\begin{tabular}{|l|l}
\hline Cost & 39. \\
\hline Time & 31 \\
\hline Quality & 37.
\end{tabular}

Quality

Earned Value

Labor productivity

Hospital performance

Customer Satisfaction

Employee Complaints

Supplier performance

Wastage

Quality initiatives that has been implemented:

\begin{tabular}{|l|l|l|}
\hline Six sigma & 0 & 0 \\
\hline Total Quality Management & 9.2 & 50.8 \\
\hline ISO $9001: 2008$ & 2.3 & 3.2 \\
\hline In process of obtaining ISO & 0 & 0 \\
\hline In-house quality system & 6.9 & 34.9 \\
\hline
\end{tabular}




\begin{tabular}{|c|c|c|}
\hline ISO 14001:2004 & 9.2 & 1.6 \\
\hline OHSAS 18001:2007 & 11.5 & 0 \\
\hline ISO 10002:2004 & 0 & 0 \\
\hline No initiative undertaken & 63.2 & 38.1 \\
\hline No initiative but interested to know about $6 \sigma$ & 63.2 & 38.1 \\
\hline ISO certified but interested in 60 & 14.9 & 39.7 \\
\hline Quality department in hospitals: & 20.7 & 69.8 \\
\hline Quality trained employees: & 29.9 & 49.2 \\
\hline \multicolumn{3}{|c|}{ How often essential trainings opportunities are provided to employees? } \\
\hline No training & 73.6 & 50.8 \\
\hline Monthly & 11.5 & 4.8 \\
\hline Semi annually & 6.9 & 1.6 \\
\hline Annually & 8 & 42.9 \\
\hline \multicolumn{3}{|l|}{ Types of trainings available to employees: } \\
\hline Process Management & 23 & 69.8 \\
\hline ISO 9000 & 2.3 & 1.6 \\
\hline Total Quality Management & 16.1 & 11.1 \\
\hline Six sigma & 0 & 0 \\
\hline Labor law & 5.7 & 0 \\
\hline Quality circles & 2.3 & 4.8 \\
\hline Management system problem solving & 8 & 25.4 \\
\hline Techniques management improvement & 26.4 & 0 \\
\hline Program benchmarking & 4.6 & 0 \\
\hline \multicolumn{3}{|l|}{ How customer satisfaction is measured? } \\
\hline Not measured & 47.6 & 63.2 \\
\hline Questionnaire survey & 3.2 & 4.6 \\
\hline Face-to-face interview & 4.8 & 12.6 \\
\hline By the number of complaints & 12.7 & 21.8 \\
\hline Follow up reports & 42.9 & 10.3 \\
\hline \multicolumn{3}{|c|}{ Factors that hinder the implementation of six sigma: } \\
\hline Lack of knowledge of the system to initiate & 74.7 & 98.4 \\
\hline Cost & 39.1 & 68.3 \\
\hline Complacency & 25.3 & 46 \\
\hline Other competing quality issues such as ISO & 17.2 & 46 \\
\hline
\end{tabular}




\section{RESULTS}

\subsection{HYPOTHESIS TESTING USING INDEPENDENT SAMPLE T-TEST}

Group statistics and independent sample t-test results are shown in the table 2. When there is no significant difference in the mean of two groups hypothesis get accepted otherwise get rejected. It is assumed that variances are equal. $\mathrm{Hl}$ got rejected. Private sector $(M=4.61)$ consider "involvement and commitment of top management" more important than Public sector $(M=4.17)$ hospitals. H2 get accepted. Private sector $(M=4.21)$ and Public sector ( $M=4.06$ ) hospitals consider "organizational infrastructure" variable equally important CSF. H3 get accepted. Private sector $(M=4.17)$ and Public sector $(M=4.11)$ hospitals consider "vision \& planning" variable equally important CSF. H4 get accepted. Private sector $(M=4.11)$ and Public sector ( $M=4.01$ ) hospitals consider "linking quality initiatives to employees" variable equally important CSF. H5 get accepted. Private sector $(M=4.27)$ and Public sector $(M=4.06)$ hospitals consider "linking quality initiatives to patients" variable equally important CSF. $\mathrm{H} 6$ get rejected. The respondents working at Public hospitals have given "project management skills" more importance than Private sector. $\mathrm{H} 7$ get rejected. The respondents working at Private hospitals have given for" information technology and innovation" more importance than Public sector. $\mathrm{H} 8$ get accepted. Private sector $(M=4.33)$ and Public sector
( $M=4.31)$ hospitals consider "communication" equally important CSF. H9 get accepted. Private sector ( $M=4.33)$ and Public sector ( $M=4.31$ ) hospitals consider "Team work" equally important CSF. H1O get rejected. The respondents working at Private hospitals have given "cultural change" more importance than Public sector. $\mathrm{H} 11$ get rejected. The respondents working at Private hospitals have given "education \& training" more importance than Public sector.

\subsection{PEARSON CORRELATION TEST}

It is evident from table 3 that "vison and planning" and "organizational infrastructure" has positive strong relationship. It means occurrence of one factor has strong positive affect on the other. "Linking quality initiatives to employees" factor has strong positive relationship with "vision and planning" factor. "Linking quality initiatives to employees" has strong positive relationship with "Linking quality initiatives to patients". "Project management skills" have positive affect on "linking quality initiatives to patients". "IT \& innovation" is strongly linked to "involvement of top management". "Communication" is strongly and positively linked to "IT \& innovation". "Team work" has strong positive relationship with "communication". "Cultural change" is strongly and positively linked with "involvement of top management". "Education \& training" has positive strong relationship with "IT \& innovation".

\section{TABLE 2 INDEPENDENT SAMPLE T-TEST (EQUAL VARIANCES ASSUMED)}

\begin{tabular}{|c|c|c|c|c|c|c|c|c|c|}
\hline \multirow{3}{*}{$\begin{array}{l}\text { CRITICAL } \\
\text { SUCCESS } \\
\text { FACTOR }\end{array}$} & \multicolumn{4}{|c|}{ LEVENE'S TEST } & \multicolumn{5}{|c|}{ T-TEST FOR EQUALITY OF MEANS } \\
\hline & $\mathbf{F}$ & SIG. & T & DF & $\begin{array}{l}\text { SIG. (2- } \\
\text { TAILED) }\end{array}$ & $\begin{array}{l}\text { MEAN } \\
\text { DIFFERENCE }\end{array}$ & $\begin{array}{l}\text { STD. ERROR } \\
\text { DIFFERENCE }\end{array}$ & \multicolumn{2}{|c|}{$\begin{array}{l}95 \% \\
\text { CONFIDENCE } \\
\text { INTERVAL LEVEL }\end{array}$} \\
\hline & & & & & & & & LOWER & UPPER \\
\hline $\begin{array}{l}\text { Involvement \& } \\
\text { commitment of } \\
\text { top } \\
\text { management }\end{array}$ & 20.088 & 0 & 2.874 & 148 & 0.005 & 0.431 & 0.15 & 0.135 & 0.727 \\
\hline $\begin{array}{l}\text { Organizational } \\
\text { infrastructure }\end{array}$ & 23.058 & 0 & 1.058 & 148 & 0.292 & 0.149 & 0.141 & -0.129 & 0.427 \\
\hline $\begin{array}{l}\text { Vision \& } \\
\text { planning }\end{array}$ & 22.593 & 0 & 0.411 & 148 & 0.682 & 0.06 & 0.145 & -0.227 & 0.346 \\
\hline
\end{tabular}




\begin{tabular}{|l|l|l|l|l|l|l|l|l|l|}
\hline $\begin{array}{l}\text { Linking quality } \\
\text { initiatives to } \\
\text { employee }\end{array}$ & 19.207 & 0 & 0.682 & 148 & 0.496 & 0.1 & 0.146 & -0.189 & 0.388 \\
\hline $\begin{array}{l}\text { Linking quality } \\
\text { initiatives to } \\
\text { patients }\end{array}$ & 13.675 & 0 & 1.431 & 148 & 0.155 & 0.212 & 0.148 & -0.081 & 0.506 \\
\hline $\begin{array}{l}\text { Project } \\
\text { management } \\
\text { skills }\end{array}$ & 5.219 & 0.024 & -2.486 & 148 & 0.014 & -0.376 & 0.151 & -0.675 & -0.077 \\
\hline $\begin{array}{l}\text { Information } \\
\text { technology \& } \\
\text { innovation }\end{array}$ & 23.484 & 0 & 2.903 & 148 & 0.004 & 0.394 & 0.136 & 0.126 & 0.662 \\
\hline Communication & 3.477 & 0.064 & 0.164 & 148 & 0.87 & 0.023 & 0.14 & -0.254 & 0.3 \\
\hline Team Work & 5.542 & 0.02 & 0.172 & 148 & 0.864 & 0.023 & 0.134 & -0.241 & 0.287 \\
\hline $\begin{array}{l}\text { Cultural } \\
\text { Change }\end{array}$ & 39.612 & 0 & 5.011 & 148 & 0 & 0.745 & 0.451 & 0.451 & 1.039 \\
\hline $\begin{array}{l}\text { Education \& } \\
\text { training }\end{array}$ & 30.789 & 0 & 2.745 & 148 & 0.007 & 0.328 & 0.12 & 0.092 & 0.565 \\
\hline
\end{tabular}

\section{TABLE 3 PEARSON CORRELATION}

\begin{tabular}{|c|c|c|c|c|c|c|c|c|c|c|c|}
\hline$\frac{\pi}{4}$ & 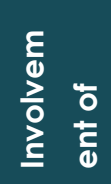 & 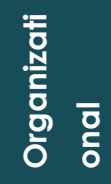 & 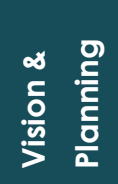 & 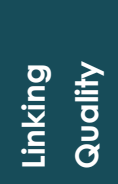 & 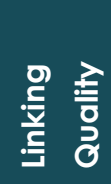 & 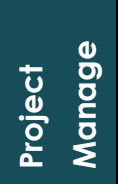 & 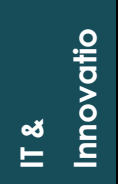 & है & 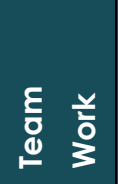 & 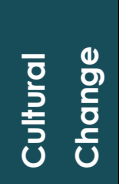 & 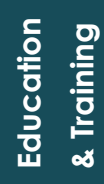 \\
\hline $\begin{array}{l}\text { Involvement \& } \\
\text { commitment of } \\
\text { top } \\
\text { management }\end{array}$ & 1 & & & & & & & & & & \\
\hline $\begin{array}{l}\text { Organizational } \\
\text { infrastructure }\end{array}$ & 0.626 & 1 & & & & & & & & & \\
\hline $\begin{array}{l}\text { Vision \& } \\
\text { planning }\end{array}$ & 0.6 & 0.825 & 1 & & & & & & & & \\
\hline $\begin{array}{l}\text { Linking quality } \\
\text { initiatives to } \\
\text { employee }\end{array}$ & 0.7 & 0.618 & 0.6 & 1 & & & & & & & \\
\hline $\begin{array}{l}\text { Linking quality } \\
\text { initiatives to } \\
\text { patients }\end{array}$ & 0.484 & 0.66 & 0.647 & 0.743 & 1 & & & & & & \\
\hline $\begin{array}{l}\text { Project } \\
\text { management } \\
\text { skills }\end{array}$ & 0.172 & 0.563 & 0.523 & 0.337 & 0.556 & 1 & & & & & \\
\hline $\begin{array}{l}\text { Information } \\
\text { technology \& } \\
\text { information }\end{array}$ & 0.695 & 0.623 & 0.609 & 0.469 & 0.517 & 0.451 & 1 & & & & \\
\hline Communication & 0.642 & 0.627 & 0.655 & 0.671 & 0.669 & 0.58 & 0.759 & 1 & & & \\
\hline Team Work & 0.557 & 0.668 & 0.603 & 0.648 & 0.638 & 0.609 & 0.698 & 0.834 & 1 & & \\
\hline $\begin{array}{l}\text { Cultural } \\
\text { Change }\end{array}$ & 0.666 & 0.545 & 0.544 & 0.573 & 0.557 & 0.262 & 0.589 & 0.599 & 0.534 & 1 & \\
\hline $\begin{array}{l}\text { Education \& } \\
\text { training }\end{array}$ & 0.653 & 0.587 & 0.613 & 0.45 & 0.467 & 0.352 & 0.828 & 0.676 & 0.665 & 0.588 & 1 \\
\hline
\end{tabular}




\section{CONCLUSION}

From the initial questions of the survey, it has been pointed out that most of the hospitals in Pakistan have not taken many initiatives regarding quality and most have their own in-house quality system. However, hospitals have shown interest in knowing more about six-sigma. This survey also pointed out that quality training is not very common among the hospital employees. CSFs were ranked differently by both sectors; based upon their resources and short-term strategic objectives. It is evident from t-test results that the top three CSFs were: Education and training, Team Work, and IT \& innovation. However, contrary to the literature review, involvement and commitment of the top management, which is one of the most important CSF, was not ranked among the top three CSFs by the employees of both sectors. And it was observed from correlation test that factors with correlation coefficient greater than 0.8 have strong and positive relationship. Thus, the need of the hour is to spread awareness about the benefits and ensure knowledge transfer of six-sigma so that it may get accepted as a new quality system. Healthcare system of Pakistan is in need of special attention and six-sigma could be one of the methods applied to resolve its problems in the long run.

\section{RECOMMENDATIONS}

Data collection was the main obstruction which was dealt with. Face to face interviews could be more helpful rather than a questionnaire. But it will require more time and resources. Due to limited time sample size is kept limited and instrument used was questionnaire. And before face to face interviews employees must be briefed about six sigma and CSFs of six-sigma. The respondents were actually briefed about six-sigma in the very beginning of the questionnaire, but it wasn't enough as perceived from the respondents' feedback. This study can be helpful in understanding the culture prevailing in healthcare system of Pakistan and what measures they have taken in order to improve or maintain service quality and how inclined they are towards six sigma implementation. What level of knowledge they have about six-sigma. This research can also be helpful in further practical implementation of sixsigma in hospitals.

\section{LIMITATIONS}

It seemed that measurement of customer satisfaction is difficult in the service sector due to human behavioural interaction. People are more resistant towards change in a service-focused environment as compared to manufacturing setting. This research was carried out with few constraints such as number of hospitals is few from few cities. The scaled questions used in the survey have disadvantage that it wasn't known why a certain response was chosen by respondent.

\section{References}

1. Akram, M. and F.J. Khan, Health care services and government spending in Pakistan, 2007, East Asian Bureau of Economic Research.

2. Organization, W.H., WHO: Ebola situation report 20 May 2015. 2015

3. Aslam, L., A. Abdullah, and R. Ayub, Analysis of Pakistan and Iran health care delivery system. International Journal of Innovative Research and Development, 2014. 3(7): p. 308-312.

4. Ali, S.W., The Poor State of Pakistan's Health System, in Dawn2016.

5. Shaikh, B.T., Private sector in health care delivery: a reality and a challenge in Pakistan. Journal of Ayub Medical College Abbottabad, 2015. 27(2): p. 496-498.

6. Allen, T.T., et al., Improving the hospital discharge process with Six Sigma methods. Quality Engineering, 2009. 22(1): p. 13-20.

7. Ahmed, S., N.H. Manaf, and R. Islam, Effects of Lean Six Sigma application in healthcare services: a literature review. Reviews on environmental health, 2013. 28(4): p. 189-194.

8. Hemant, U., Six Sigma for Business Excellence: Approach, Tools and Applications2011: Pearson Education India.

9. Pyzdek, T., The six sigma. Estados Unidos: Mcgrawhill, 2003.

10. Tsironis, L.K. and A.G. Psychogios, Road towards Lean Six Sigma in service industry: a multi-factor integrated framework. Business Process Management Journal, 2016. 22(4): p. 812-834. 
11. Voehl, F., et al., The lean six sigma black belt handbook: tools and methods for process

acceleration2013: Productivity Press.

12. Taner, M.T., Critical success factors for Six Sigma implementation in large-scale Turkish construction companies. International Review of Management and Marketing, 2013. 3(4): p. 212-225.

13. Antony, J., et al., Six sigma in service organisations: Benefits, challenges and difficulties, common myths, empirical observations and success factors. International journal of quality \& reliability management, 2007. 24(3): p. 294-311.

14. Yeh, H.-L., et al., Applying lean six sigma to improve healthcare: An empirical study. African Journal of Business Management, 201 1. 5(31): p. 12356-12370.

15. Ratnaningtyas, D.D. and K. Surendro, Information quality improvement model on hospital information system using six sigma. Procedia Technology, 2013. 9: p. 1166-1172.

16. Al Owad, A., M. Karim, and L. Ma. Integrated Lean Six Sigma approach for patient flow improvement in hospital emergency department. in Advanced Materials Research. 2014. Trans Tech Publ. 17. J. Liberatore, M., Six Sigma in healthcare delivery. International journal of health care quality assurance, 2013. 26(7): p. 601-626.

18. Jayanta K. Bandyopadhyay, K.C., Six Sigma Approach to Healthcare Quality and Productivity Management International Journal of Quality \& Productivity Management, 2005. 5(1): p. 12.

19. Lazarus, I.R. and C. Neely, Six sigma raising the bar. Managed Healthcare, 2003. 13(1): p. 31-31.

20. Bandyopadhyay, J.K. and K. Coppens, The use of six sigma in healthcare. Intl J Prod Qual Manag, 2005. 5(1): p. v1-v12. 